\title{
An Assessment of Microbiological Quality of Some Commercially Packed and Fresh Fruit Juice Available in Dhaka City: A Comparative Study
}

\author{
Tasmina Rahman, ${ }^{1}$ Sabrina Hasan, ${ }^{1}$ and Rashed Noor $^{1 \neq}$ \\ ${ }^{1}$ Department of Microbiology, Stamford University Bangladesh
}

Received 10 July 2010/Accepted 17 August 2010

\begin{abstract}
Fruit juices are regarded as the most preferred non-alcoholic beverage worldwide to all age groups. In general, microbial growth in fruit juice is restricted by using preservatives and also through other environmental factors during production. Still, the presence of some indicator organisms in fruit juice is responsible for causing food-borne diseases and even death. So, from public health point of view, it is quite important to know the microbiological quality of the fruit juices available in the market. Primary objective of this study was to assess the microbial quality of fresh and commercially packed available juices collected from different locations of Dhaka city. A total of six fresh juice and nine commercially packed juice samples were collected. Standard culture techniques were followed to assess total viable count (TVC), total staphylococcal count (TSC), total Bacillus count (TBC) and total fungal count (TFC) on different culture media. The TVC varied from the range of $10^{2}$ to $10^{5} \mathrm{cfu} / \mathrm{ml}$ with the highest of $2.4 \times 10^{5} \mathrm{cfu} / \mathrm{ml}$. A large number of staphylococci and Bacillus was also found from several samples. Total coliform and fecal coliform was found in six and five (out of fifteen) samples, respectively. Among total coliforms, Klebsiella, Enterobacter along with $E$. coli were detected. From all the assessment it was determined that the microbial quality of commercially packed juice was fairer than that of fresh juice collected from local market.
\end{abstract}

In recent years, the increasing consumer awareness has emphasized the need for microbiologically safe food. Since the human food supply consists basically of plants and animals or products derived from them, it is understandable that our food supply can contain microorganisms in interaction with the foods. When the microorganisms involved are pathogenic, their association with our food is critical from a public health point of view. Serious health hazards due to the presence of pathogenic microbes in food can lead to food poisoning outbreaks (1). Freshly extracted fruit juices, which have always been considered as healthful drink, may not always be safe owing to the heavy load of microbes (2). In a situation where storage of juice is indispensable may be for a short duration, then the use of simple processing techniques soon after its extraction is essential for improving the keeping quality to ensure it's safety, nutritive quality and acceptability while consumption. Preservation of fruit juice by pasteurization, refrigeration and sterilization are popular methods used to attain microbiological stability by destroying pathogenic microorganisms and to preserve the color, aroma and taste of fresh juice (3).

${ }^{\ddagger}$ Corresponding Author. Mailing address: Dr. Rashed Noor, Department of Microbiology, Stamford University Bangladesh, 51, Siddeswari Road, Dhaka, Bangladesh. Phone: +88-02-8354577 (Ext-472), Fax: +88-02-9143531, Email: noor.rashed@yahoo.com .
As indicated, the sources of fruits that can be made into juices are nearly limitless in plants and the plant parts appropriate for juice. However, the fruit producers and juice processors must adhere to some very important guidelines in fruit selection and juice manufacture (4). Environmental sources of contaminating organisms of juices are carefully considered as these microbes invade the drink preparations during processing, packaging and handling $(5,6)$.

The major ingredients of the juice such as water, sugar, natural fruit pulp etc may also carry some microbial contaminants. Food-borne illness is commonly caused by certain bacteria or their toxins, which are poisonous proteins produced by these bacteria (7). The most common food borne pathogenic bacteria are Bacillus cereus, Clostridium botulinum, Escherichia coli, Shigella spp., Salmonella spp., Vibrio parahaemolyticus, Staphylococcus aureus, Campylobacter jejuni, Streptococcus pyogenes, Mycobacterium bovis, Listeria monocytogenes etc. In pregnant women, the fetus is most heavily infected, leading to spontaneous abortion, stillbirths, or sepsis in infancy (8). Contamination of juices with pathogenic microorganisms such as E. coli and Salmonella spp. has caused numerous illness and even some fatalities $(9,10)$.

The fruit producers and juice processors must adhere to some very important guidelines in fruit selection and juice manufacture. The juices contain mainly water, sugar, preservatives, color, fruit pulps and other additives (Table $1)$. 
TABLE 1. The recommended microbiological standards for any fruit juice; all numbers are as per ml of juice consumed (11)

\begin{tabular}{ccccc}
\hline Parameter & Total viable count & Coliform & Fecal coliform & Staphylococci \\
& & & & \\
\hline Maximum count anticipated & $5.0 \times 10^{3}$ & 10 & 0 & 100 \\
Maximum count permitted & $1.0 \times 10^{4}$ & 100 & 0 & $1.0 \times 10^{3}$ \\
\hline
\end{tabular}

TABLE 2. List of collected samples

The presence of microbial contaminants in water, sugar and pulp may cause spoilage of the drinks or gastrointestinal diseases to the consumers (4).

Industrially processed fruit juices were investigated for some physicochemical tests. They apply chemical preservatives that can inhibit all types of microbial growth. It is well known that the manufacturers commonly use Sulphur Dioxide $\left(\mathrm{SO}_{2}\right)$ and benzoate as preservatives in processed fruit juices. Sulphur dioxide and benzoate can significantly damage the vegetative cells. The sulphites inhibit yeasts, moulds and bacteria and are most effective as inhibitors of browning in foods (8). They also reduce the number of growth of microbes and increase the shelf life of juice products.

The effect of storage temperature has also been reported in various research papers. At $4{ }^{\circ} \mathrm{C}$ nutritional values of juice were longer than 25 days in all system tested (12). In another study, while the refrigeration condition was able to stabilize Rosselle fruit flavored drinks for a week, the freezing condition was able to preserve the drinks for more than a week (13).

The focus of this study was to compare the quality of fresh and commercially available fruit juices by assessing their microbial load and the presence of pathogenic bacteria.

\section{MATERIALS AND METHODS}

Sample collection. Fifteen samples were collected, of which 6 fresh juice samples were collected from 5 different locations of Dhaka city and other 9 juice samples were commercially packed juices available in market. The table of collection sites are given below (Table 2).

Enumeration of total bacteria. A total of $1 \mathrm{ml}$ of sample was transferred with a sterile pipette to the tube containing $9 \mathrm{ml}$ of ringer solution to make $10^{-1}$ dilution. In such a way, dilution upto $10^{-6}$ was made. If in any sample countable number of colonies were detected at $10^{-6}$ dilution, further dilution of same item were prepared and tests were repeated using ringer solution. All colonies on the dishes were counted using a colony counter and following back calculating the actual numbers of bacteria.

To enumerate the microbial load in the fruit juice sample, Plate Counting Agar (PCA) (Hi Media, India) for total viable bacterial count (TVC), Dextrose Tryptose Bromocresol Purple Agar (DTBPA) (Difco, USA) for total Bacillus count (TBC), Baired Parker Agar (BPA) (Difco, USA) for total Staphylococcal count (TSC), and Potato Dextrose Agar (PDA) (Hi Media, India) for total fungal count (TFC) were used.

Isolation and identification of coliform. For presumptive identification of coliform bacteria, samples were inoculated onto MacConkey agar media. The isolates were then inoculated in Brilliant Green Lactose Bile (BGLB) broth followed by streaking on Eosine Methylene Blue (EMB) agar plate. Indole test, Methyl red test and Citrate utilization test were done to differentiate among groups of coliform bacteria. All media were prepared in the laboratory according to the manufacturer's instruction. After inoculation of the samples, plates were incubated at $37^{\circ} \mathrm{C}$ and colonies were obseved after 24 hours.

\begin{tabular}{cll}
\hline Fresh juice & Collection area & Sample no. \\
\hline Orange & Moghbazar & FO1 \\
Orange & Siddeswari & FO2 \\
Papaya & Khilgaon & FPA \\
Pineapple & Mirpur & FPI \\
Sugarcane & Farmgate & FS1 \\
Sugarcane & Farmgate & FS2 \\
& & \\
\hline Commercially packed juice & Brand & Sample no. \\
\hline Orange & Brand A & COA \\
Orange & Brand B & COB \\
Orange & Brand C & COC \\
Orange & Brand D & COD \\
Mango & Brand A & CMA \\
Mango & Brand B & CMB \\
Mango & Brand C & CMC \\
Mango & Brand D & CMD \\
Apple & Brand E & CAP \\
\hline
\end{tabular}

\section{RESULTS}

Microbial load in fresh juice samples. The mean bacterial count in fresh juice samples was $1.14 \times 10^{4}$ $\mathrm{cfu} / \mathrm{ml}$. The total viable count varied with different types of juices that ranged from $3.2 \times 10^{2}$ to $2.4 \times 10^{4} \mathrm{cfu} / \mathrm{ml}$. Similarly, we found mean staphylococcal count as $7.2 \times 10^{3}$ $\mathrm{cfu} / \mathrm{ml}$ with the range from 0 to $2.5 \times 10^{4} \mathrm{cfu} / \mathrm{ml}$. In case of total Bacillus count, we found that the mean count was $7.2 \times 10^{3} \mathrm{cfu} / \mathrm{ml}$ and it ranged from 0 to $2.5 \times 10^{3} \mathrm{cfu} / \mathrm{ml}$ in different fruit juice samples (Fig. 1).

Microbial load in commercially packed juice sample. The mean bacterial count in commercially packed juice samples was $1.8 \times 10^{3} \mathrm{cfu} / \mathrm{ml}$. The total viable bacterial count varied with types of juices as well as different brands of same type of juices that ranged from $3.1 \times 10^{2}$ to $3.2 \times 10^{3} \mathrm{cfu} / \mathrm{ml}$. Likewise, we found mean Staphylococcal count as $4.9 \times 10^{2} \mathrm{cfu} / \mathrm{ml}$ with the range from 0 to $2.3 \times 10^{3}$ $\mathrm{cfu} / \mathrm{ml}$. Moreover, mean Bacillus count was found $7.3 \times 10^{2}$ $\mathrm{cfu} / \mathrm{ml}$ and it ranged from $1 \times 10^{2}$ to $2.0 \times 10^{3} \mathrm{cfu} / \mathrm{ml}$ in different types and brands of fruit juice samples (Fig. 1 \& 2).

Total fungal count. The total fungal count was observed on potato dextrose agar (PDA) media. The single medium used for the enumeration of fungi showed a little range of growth from $2.3 \times 10^{2}$ to $9.0 \times 10^{6} \mathrm{cfu} / \mathrm{ml}$ (Table 3). 


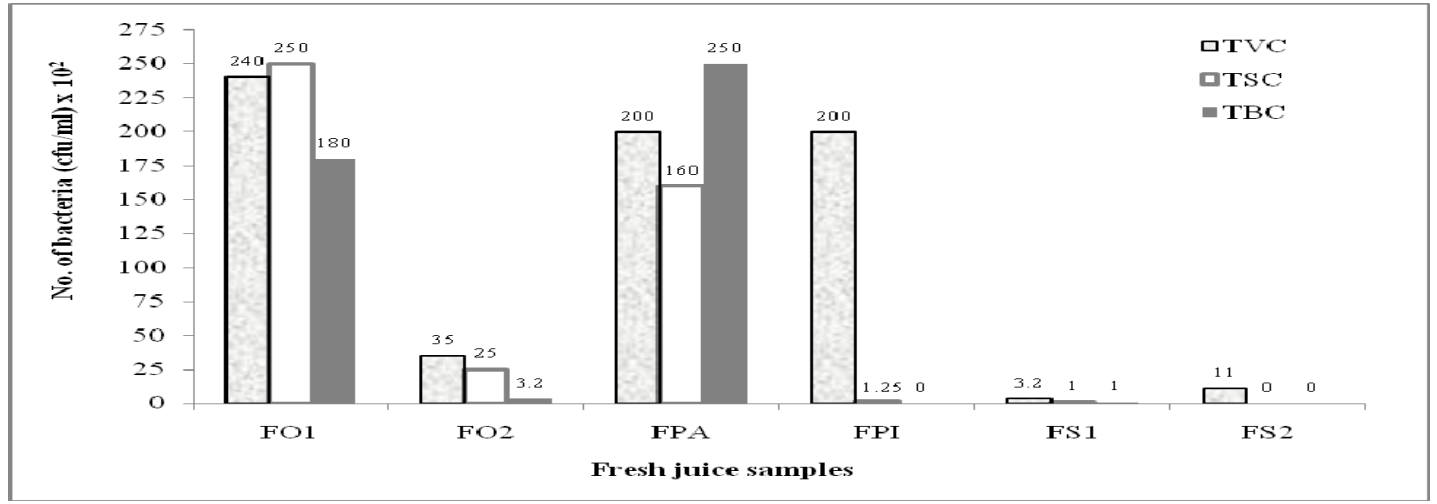

(A)

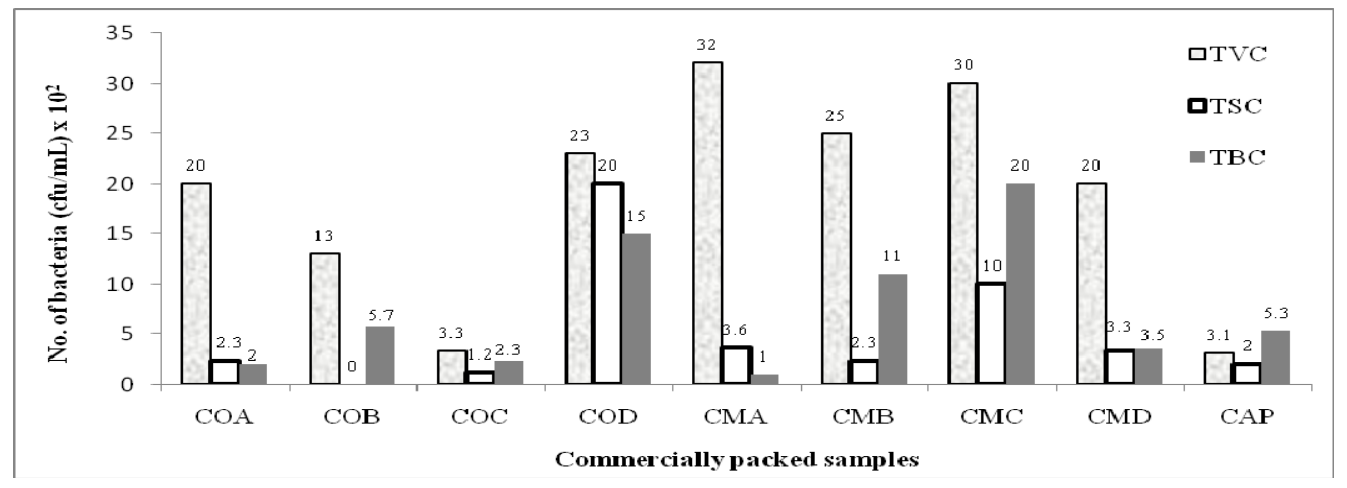

(B)

FIG. 1. Total viable bacterial count, total Staphylococcal count and total Bacillus count in (A) fresh juice (B) commercially packed juice samples

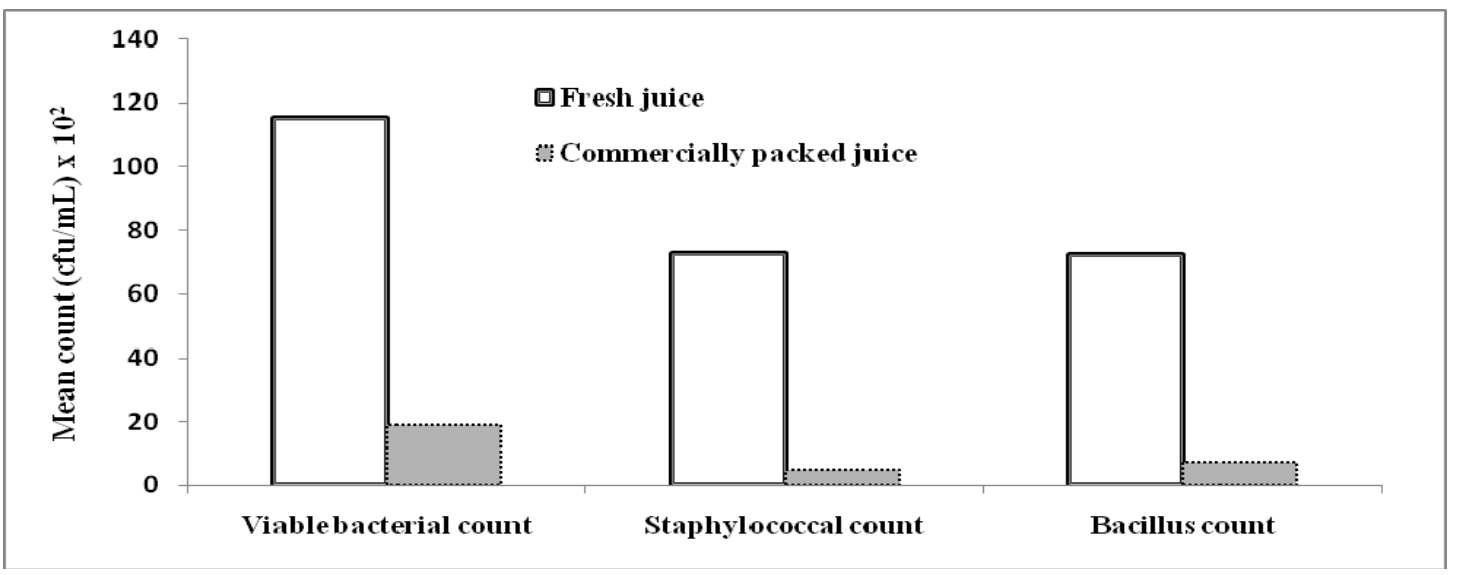

FIG. 2. Comparative mean viable bacterial count, Staphylococcal count and Bacillus count between fresh juice and commercially packed juice samples 
TABLE 3. Total fungal count of the tested samples in the PDA media

\begin{tabular}{ccc}
\hline Fresh juice & Sample no. & Average no. of fungal count (cfu/ml) \\
\hline Orange & FO1 & $9.0 \times 10^{6}$ \\
Orange & FO2 & $5.5 \times 10^{3}$ \\
Papaya & FPA & $4.5 \times 10^{4}$ \\
Pineapple & FPI & $5.4 \times 10^{5}$ \\
Sugarcane & FS1 & $8.1 \times 10^{3}$ \\
Sugarcane & FS2 & $2.3 \times 10^{2}$ \\
\hline & & \\
\hline Commercially packed juice & Sample no. & $8.4 \times 10^{4}$ \\
\hline Orange & COA & $2.2 \times 10^{3}$ \\
Orange & COB & $5.7 \times 10^{6}$ \\
Orange & COC & $2.2 \times 10^{4}$ \\
Orange & COD & $3.5 \times 10^{6}$ \\
Mango & CMA & $2.5 \times 10^{4}$ \\
Mango & CMB & $4.2 \times 10^{3}$ \\
Mango & CMC & $8.2 \times 10^{4}$ \\
Mango & CMD & $5.2 \times 10^{4}$ \\
Apple & CAP & $\mathrm{cfu} / \mathrm{ml})$ \\
\hline
\end{tabular}

TABLE 4. Presence or absence of total coliform and fecal coliform in the fruit juice

\begin{tabular}{ccc}
\hline Sample no. & Presence of total coliform $^{\mathrm{a}}$ & Presence of fecal coliform \\
\hline FO1 & + & Positive \\
FO2 & - & Negative \\
FPA & + & Positive \\
FPI & + & Positive \\
FS1 & + & Positive \\
FS2 & - & Negative \\
COA & + & Negative \\
COB & + & Positive \\
COC & - & Negative \\
COD & - & Negative \\
CMA & - & Negative \\
CMB & - & Negative \\
CMC & - & Negative \\
CMD & - & Negative \\
CAP & - & Negative \\
\hline a
\end{tabular}

${ }^{\text {a }}$ : positive; -: negative

Isolation of the total coliform and fecal coliform bacteria. In the confirmatory test for the presence of coliform bacteria in the fruit juice, the samples were inoculated on the EMB agar media (Table 4).
Identification of the total coliform. The isolated coliforms were further inoculated in different biochemical media for the differentiation among the groups. On the basis of those tests, the bacteria were identified to the genus level. The result is given in the following table (Table 5). 
TABLE 5. Identification of the total coliforms

\begin{tabular}{ccccc}
\hline Sample no. & Citrate utilization test $^{\mathrm{a}}$ & Methyl red test $^{\mathrm{a}}$ & Indole test $^{\mathrm{a}}$ & Suspected Organism \\
\hline FO1 & - & + & + & E. coli \\
FPA & - & + & + & E. coli \\
COA & + & - & - & Enterobacter \\
COB & + & - & - & Enterobacter \\
FS1 & + & + & - & Klebsiella \\
FPI & + & - & Enterobacter \\
\hline
\end{tabular}

\section{DISCUSSION}

Fruit juices are very popular among the people of all ages around the world. Also in Bangladesh, ready to eat packed fruit juice is becoming more and more popular as they are usually tastier than soft drinks. Advantage of packed fruit juices is that these are convenient to carry and can be kept for a considerable amount of time $(14,15)$. Fruit juices by their very nature contain various organisms. Clearly, many of these microorganisms will be harmless yeasts \& saprophytic bacteria. By detecting this bacterial load in the juice, it apparently gives an idea about the quality of the sample. Therefore, aerobic plate count or total counts of some popular juice were carried out in the present experiment.

Total viable bacterial count in most of the fresh juice samples was higher than the commercially packed juice, as the highest count was found as $2.4 \times 10^{4} \mathrm{cfu} / \mathrm{ml}$ and $3.2 \times 10^{3} \mathrm{cfu} / \mathrm{ml}$ in fresh and packed juice, respectively. The scenario of total staphylococcal and Bacillus count was also similar. Though most of the juice samples showed equal or slightly higher count than the permitted count (11), these were unfavorable for consumption because six of them showed the presence of coliform. The presence of coliform in fruit juice is not allowed by safe food consumption standard (14). Coliforms were identified as E. coli, Enterobacter and Klebsiella, which can produce many systematic infections after consumption.

The fungal count was also much higher in many samples and varied from sample to sample. Though the fungal isolates were not identified, colony morphology and color showed the probability of the presence of pathogenic strain and could produce mycotoxins in juice samples.

The comparative study anticipated the safe consumption of commercially packed juice than the freshly packed juice marketed locally. This might be the reason of using automated machine and also some preservatives during fruit juice processing. But some preservatives of higher concentrations can be harmful for our health. Therefore studies on preservative concentrations should also be carried out.
The juices that are mishandled and mistreated during preparation or storage generally cause most outbreaks. The disease agents spread by juice like drink not only harm large groups of people but also sometimes result in serious disability and death. The lack of knowledge in cleaning, safe fruit juice preparation and contamination sources can contribute to the contamination process unknowingly to the people working in fruit juice industries. It is therefore, essential for the people who handle and prepare juices, to be properly trained in safe fruit handling technique.

The microbiological quality of processed fruit juices is the most important aspect to be taken care of by the manufacturer. Negligence in this area may result in serious contamination that ultimately represents a low quality product to the consumers. As these unwanted unhygienic conditions are usually due to the lack of knowledge and unawareness to the fundamental sanitary principles, it is preventable by proper training and monitoring. The government authorized institute (like BSTI) should take intensive investigation to control the microbial and chemical quality of the juices as well as the public awareness about the adulterated fruit juices should be increased.

\section{REFERENCES}

1. Frazier, W. C., and D. C. Westhoff. 1997. Food Microbiology. Tata McGraw-Hill, inc., New York.

2. Kumari, V. 1995. Nutritional and microbial quality of sugarcane juice in Udaipur city. M. Sc. dissertation, RAU, Bikaner.

3. Elmahmood, A. M., and J. H. Doughari. 2007. Microbial quality assessment of kununzaki beverage sold in Girei town of Adamawa State, Nigeria. Afr. J. Food Sci. 1(1):11-15.

4. Eckert, J. W. 1979. Fungicidal and fungistatic agents: Control of pathogenic microorganisms on fresh fruits and vegetables after harvest, $\mathrm{p}$ 149-164. In Food mycology. Hall, Boston.

5. Jay, J. M. 1987. Physical, Chemical, Molecular and Immunological Methods, p. 200-209. In Modern Food Microbiology, 3rd ed. CBS publishers and distributors, India.

6. Audurier, A., and C. Martin. 1989. Phage typing of Listeria monocytogenes. International Journal of Food Microbiology 8(3):251-257.

7. Bryan, F. L. 1977. Diseases transmitted by food contaminated with wastewater. J.Food Protection 40:45-56.

8. Prescott, L. M., J. P. Harley, and D. A. Kleen. 2002. Microbiology, 5th ed. McGraw Hill, New York.

9. Cody, S. H., et al. 1999. An outbreak of Escherichia coli 0157:H7 Infection from Unpasteurized Commercial Apple Juice. Annals of Internal Medicine 130(3):202-209. 
10. Boase, J., et al. 1999. Outbreak of Salmonella Serotype Muenchen Infections Associated with Unpasteurized Orange juice-United States and Canada. JAMA 282: 726-728

11. Gulf Standards. 2000. Microbiological criteria for foodstuffs, Part 1. GCC, Riyadh, Saudi Arabia.

12. Doughari, J. H., G. Alabi, and A. M. Elmahmood. 2007. Effect of some chemical preservatives on the shelf-life of sobo drink. African Journal of Microbiology Research 2:37-41.
13. BSTI. 2005. Bangladesh Standard Specification for Drinking Water, BDS 11150. Bangladesh Standard and Testing Institute (BSTI), Dhaka.

14. Andres, S. C., L. Giannuzzi, and N. E. Zaritzky. 2004. The effect of temperature on microbial growth in apple cubes packed in film and preserved by use of orange juice. International Journal of Food Science \& Technology 39(9):927-933.

15. Morris, E. O. 1962. Effect of environment on microorganisms, p. 2436. In Recent advances in food science, vol. 1. Butterworth, London. 